tered. We reached Walla Walla about $9: 30$. The country from Spokane to Walla Walla is an excellent grazing region but barren, dusty and unattractive in appearance, with alkali dust, and scarcity of water. As we left Walla Walla, with our train for the first time headed homeward, the travelers were happy; and a concert was started in the smoking car led by the Actor Stuart, who happened to be on board; his voice is a high tenor, and all were charmed with his comic and sentimental songs, but our pleasure was of short duration for three of our cars were suddenly derailed, and our Pullman was thrown sideways in a way that was unpleasant to say the least. A broken rail, mashed ties and warped brakes gave rise to much growling, but, as nobody was hurt, the status quo ante accidens was soon regained, a fire was built of broken ties along side of the track and story telling was resumed. Many speculations were indulged in regard to the cause of the accident. Some had noticed a cross-eyed man get aboard the train at the Snake River bridge; the brakeman acknowledged in a moment of confidential candor that a friend of his had given him an opal ring that day, with the cheerful assurance that his train would be ditched before night, and however near the mark these speculations may have come, a hard matter-of-fact passenger declared after examining the rail that it was "structurally defective," having been an old rail refaced, and that the ties were spongy with dry rot. As the speaker was a railroad contractor of much experience, this seemed to settle it, but the brakeman was seen to turn his opal ring to the inside of his finger where he could now and then cast deprecatory glances at it unobserved. As for the cross-eyed passenger, he disappeared shortly after the wreck, and was seen no more. Our train was after a while righted and we again started, chastened in spirit but not cast down. June 14 a dining car was put on the train at Pendleton, Oregon, and we breakfasted with comfort. All day long we were engaged in crossing and re-crossing Snake River, inhaling alkali dust and looking out on the hot arid wastes of sage brush and sand. We saw the mining shafts in the side hills near Baker City, where the placer mines are fairly productive, and just above Huntington we came upon the prison camp where a portion of the Coxey tramps are serving out a sentence of the Federal Court under guard of a detachment of regular troops from the Fourth and Fourteenth Infantry. The commanding officer in conversation informed us that these people were the toughest of their class. They were kept in a small level area of about four acres between the embankment of the railroad and the river, with high alkali hills on either side, without shade and exposed to the violent rays of a scorching sun. Notwithstanding their condition the majority absolutely refused to work when lumber and materials were furnished them for the construction of a barrack for their own accommodation-14 men out of 175 were willing, and began to put up the barracks, but were obliged by the remainder of the "unemployed" to cease work. The commanding officer then detailed a guard to protect them while at work and the building of the barracks was in progress as we passed. It is safe to say that our "boys in blue" were not enthusiastic about the nature of the duty. June 15 our train arrived at Montpelier, Idaho, at about 7 A.M., and barring the mosquitos, which were the most vicious of their class, we were in a pleasant region; snow-capped mountains surrounded us, and Bear River, a clear and beautiful trout stream, was full to its banks. The remainder of the journey was without incident and we arrived in Chicago June 17.

\section{South Carolina Practice of Medicine Act.}

Aiken S. C., June 9, 1894.

To the Editor:-In the issue of your paper March 10, 1894, page 355 in the article, "Legal Requirements for the Prac- tice of Medicine in the United States," you have the law for South Carolina wrong; please correct it as it is apt to mislead doctors wishing to come in the State to practice.

The Legislature of 1893 passed a law which went into effect Jan. 4, 1894. The law provided for the appointment of a State Board of Medical Examiners to be composed of seven members, whose duty it is to examine all candidates who wish to practice"medicine in the State and who were not registered Jan. 4, 1894. The candidate must first show his diploma and he is then given a written examination of two hours on each of the seven principal branches. The next meeting of the Board is Oct. 9, 1894, at Columbia, S. C. Yours truly, C. F. McGahan.

\section{The Physicians' Sanitarium.}

SAN Francisco, June 8, 1894.

To the Editor:-There is an error in the announcement of the Physicians' Sanitarium which appeared in your issue of May 5 and possibly in subsequent issues.

I am not connected with that institution in that. or any other capacity.

While I did contemplate connecting myself with that enterprise and deem such an institution, conducted on ethical lines, a proper enterprise in which physicians might and should engage, I declined permitting my name to be used in connection therewith upon seeing a circular emanating from a business manager thereof, and though the circulars have since been withdrawn I have yet no connection with that institution.

I make this statement with no intention to reflect upon the present management of the said institution, which I believe to be now ethically conducted.

Respectfully,

C. H. Hughes, M.D., St. Louis.

\section{Correction.}

OTTAWA, CAN., June 6, 1894.

To the Editor:-It has but just come to my notice that there are several unpleasant typographical errors in my paper on Physiotherapy in the Journal of May 26, and which I corrected in revised proof. I presume you did not receive proof before going to press. Besides errors in the Greek lettering, in spelling two or three proper names and in punctuation, especially in breaking with a period and a capital the last sentence (a long one, to be sure) in the first paragraph, there are errors in the last paragraph which would lead a hasty reader to think it was I who had started the "water cure." Instead of, "I placed myself under the care of a Mr. Brown, who had during the time of Priessnitz a popularity which extended to the uttermost parts of the earth ; and started a . . 'water cure," kindly make it read : "Brown, who had during the time of Priessnitz's popularity. which extended, etc., started a 'water cure.'"

Edward Playter.

\section{NECROLOGY.}

William T. Briggs, M.D., of Nashville, Tenn., June 13. He was born at Bowling Green, $\mathrm{K}_{y}$., Dec. 4 , 1828, and received his literary education in the schools of his native town. $\mathrm{He}$ then graduated in medicine at the Transylvania University at Lexington, $\mathrm{Ky}_{\mathrm{y}}$, when not 21 years of age. He returned to Bowling Green, $\mathrm{Ky}$., and entered the practice of medicine with his father. He remained there three years when he was elected Demonstrator of Anatomy in the Medical Department of the University of Nashville. This was in 1852 and he removed to that city at once and has lived there ever 